\title{
Larvicidal Activity of Leaf Extract From Mauritiella armata (Aceraceae) on Aedes aegypti and Culex quinquefasciatus (Culicidae)
}

\author{
Rosanna Lorrane Francisco dos Reis Matos ${ }^{1}$, Núbia Nunes de Souza ${ }^{1}$, Sandro Morais dos Santos ${ }^{2}$, \\ Aline Ferreira Rafael ${ }^{1}$, Eduardo Robson Duarte ${ }^{2}$, Katchuce Brito Amarante Oliveira ${ }^{2}$, \\ Filipe Vieira Santos de Abreu ${ }^{3}$, Franciellen Morais-Costa ${ }^{1}$, Sônia Ribeiro Arrudas ${ }^{1}$, \\ Islaine Franciely Pinheiro de Azevedo ${ }^{1}$, Yule Roberta Ferreira Nunes ${ }^{1}$, \\ Ana Paula Venuto Moura ${ }^{1} \&$ Thallyta Maria Vieira ${ }^{1}$ \\ ${ }^{1}$ Universidade Estadual de Montes Claros, Montes Claros, Minas Gerais, Brazil \\ ${ }^{2}$ Instituto de Ciências Agraria, Universidade Federal de Minas Gerais, Montes Claros, Minas Gerais, Brazil \\ ${ }^{3}$ Instituto Federal do Norte de Minas Gerais, Salinas, Minas Gerais, Brazil \\ Correspondence: Rosanna Lorrane Francisco dos Reis Matos, Universidade Estadual de Montes Claros, Campus \\ Universitário Prof. Darcy Ribeiro, Av. Prof. Rui Braga, s/n-Vila Mauriceia, Montes Claros, Minas Gerais \\ 39401-089, Brazil. Tel: 55-38-9867-2264. E-mail: rosannalorranee@gamil.com
}

\author{
Received: November 7, 2021 \\ Accepted: January 6, 2022 \\ Online Published: January 15, 2022 \\ doi:10.5539/jas.v14n2p63 \\ URL: https://doi.org/10.5539/jas.v14n2p63
}

This research was supported by the Long-term Ecological Research Network (PELD-VERE) of the Conselho Nacional de Desenvolvimento Cientifico e Tecnológico (CNPq 441440/2016-9; 441583/2020-2; 308877/2019-5), the Coordenação de Aperfeiçoamento de Pessoal de Nivel Superior (CAPES 88887.136273/2017-00), the Fundação de Amparo à Pesquisa do Estado de Minas Gerais (FAPEMIG APQ-04816-17; CRA-PPM-00539-18), and the Ministério da Ciência, Tecnologia e Inovações. And also through the Academic Excellence Program (PROEX-CAPES), process 23038.005150/2018-15, grant 0802/2018 from the Graduate Program in Health Sciences of the State University of Montes Claros.

\begin{abstract}
The mosquitoes Aedes aegypti and Culex quinquefasciatus (Diptera: Culicidae) are important vectors of several arboviruses, and are relevant public health problems. Conventional control, using chemical larvicides have selected resistant Culicidae populations and caused negative effects on the environment and human health. However, the use of plant extracts has represented a sustainable alternative for insect control. Popularly known as Xiriri, Mauritiella armata (Mart.) Burret (Aceraceae) is an abundant palm tree in Vereda ecosystems and has economic and social importance. In this study, the aim was to evaluate the larvicidal activity of the aqueous extract (AE) leaves of this plant on Ae. aegypti and Cx. quinquefasciatus larvae. The mortalities of larvae were analyzed after treatment with four concentrations of the extract, comparing with a negative control using mineral water. The AE promoted $100 \%$ efficacy against Ae aegypti larvae at $7.9 \mathrm{mg} / \mathrm{mL}$. The lethal concentration to promote $90 \%$ mortality of $C x$. quinquefasciatus larvae was estimated at $30.57 \mathrm{mg} / \mathrm{mL}$. After chromatographic analyses, flavonoids, catechin and carbohydrates were detected. AE from $M$. armata leaves presented high larvicidal activity against $A$ e. aegypti and $C x$. quinquefasciatus, and represents a promising alternative to be used in vector control.
\end{abstract}

Keywords: arboviruses, plant extract, palm tree and unique health

\section{Introduction}

Vector-borne diseases account for 17\% of the estimated global burden of all infectious diseases (WHO, 2018). Aedes aegypti (Linnaeus, 1762) and Culex quinquefasciatus (Say, 1823) are vectors of several arboviruses, which are considered a public health problem due to their increasing territorial dispersion, high capacity to adapt to artificial ecotopes and difficulty to be controlled (Donalisio, Freitas, \& Zuben, 2017).

Vector control is the main form of prevention, and the elimination of breeding sites is the most effective method; however, conventional treatments with chemical larvicides select resistant populations of Culicidae (Gray et al., 2018; Atyame et al., 2019; Lopes et al., 2019). As a result, the use of plant extracts appears as a promising 
alternative, ecologically and environmentally safe, and biodegradable, contributing to the reduction of negative effects on the environment and public health (Hwang et al., 2017; Hari \& Mathew, 2018).

Mauritiella armata (Mart.) Burret belongs to the Arecaceae family and is popularly known as Xiriri. It is a palm tree widely distributed in the Brazilian territory, in the Vereda areas and has economic and social importance for the Vereda communities (Andrew Henderson, 1995; Martins, 2012). Although some studies have shown that plants of the Arecaceae family have a larvicidal effect against Culicidae larvae (Tayler et al., 2019, Koc et al., 2016), the phytochemical composition of M. armata extracts and the potential of metabolites in the control of insects however, are not known. In this perspective, the study proposed to evaluate the larvicidal activity of aqueous extract of Mauritiella armata leaves on Aedes aegypti and Culex quinquefasciatus.

\section{Method}

\subsection{Plant Material}

The plant material was composed of leaves of Mauritiella armata, from the Almescla vereda of the Pandeiros Environmental Protection Area, located in northwestern Minas Gerais, Brazil $\left(15^{\circ} 22^{\prime} 50^{\prime \prime} \mathrm{S}\right.$ and $\left.44^{\circ} 55^{\prime} 28^{\prime \prime} \mathrm{W}\right)$. The desiccated leaves were deposited at the Montes Claros Herbarium: MCMG and identified as Mauritiella armata (Mart.) Burret (xiriri), receipt $\mathrm{n}^{\circ} 5778 \mathrm{a}$.

\subsection{Production of Extract}

Leaves of M. armata were selected and washed in running water, and damaged or deteriorated were discarded. Afterwards, they were dehydrated in a greenhouse with forced air circulation at $40{ }^{\circ} \mathrm{C}$ for 72 hours and ground in a feed mill. The resulting material was placed in paper bags, free from the incidence of light.

The aqueous extract (AE) was prepared by adding $500 \mathrm{~mL}$ of distilled water to $50 \mathrm{~g}$ of raw powder of the plant species, being heated in a water bath at $40{ }^{\circ} \mathrm{C}$ for $60 \mathrm{~min}$. After this period, the extracts were hot filtered in a funnel with gauze and cotton and later sent to a greenhouse with forced air circulation at $40{ }^{\circ} \mathrm{C}$ until constant weight was obtained (Nery et al., 2010, Morais-Costa et al., 2015).

The subsamples of the extracts were submitted to dry matter determination at $105{ }^{\circ} \mathrm{C}$, to calculate the tested concentrations (Patricia Cunniff, 1995). After determining the dry matter weight, the extracts were adjusted to the concentrations to be tested.

\subsection{Chromatographic Analysis of the Extract}

Quotas $(1.0 \mathrm{mg})$ of the plant extract was measured in a conical glass and then dissolved in $60 \mu \mathrm{L}$ of pyriride and $100 \mu \mathrm{L}$ of BSTFA (N,O-bis(trimethylsilyl) = triflouroacetamide) containing $1 \%$ of chloratrimethylsilane. The reaction mixture was heated at $60^{\circ} \mathrm{C}$ for $30 \mathrm{~min}$. Of the solution obtained, only $1 \mu \mathrm{L}$ was injected into the CG-MS, and the procedure was performed in triplicate.

Chromatographic analyses were performed in an Agilent Technologies gas chromatograph (GC 7890A) equipped with an electron impact ionization detector (CG-MS) and a DB-5MS capillary column (Agilent Technologies, 30 $\mathrm{m}$ long $\times 0.25 \mathrm{~mm}$ internal diameter $\times 0.25 \mu \mathrm{m}$ film thickness). Helium $(99.9999 \%$ purity) was used as the trailing gas at a rate of $1 \mathrm{~mL}$ min-1. Using an autoinjector (CTC combiPaL), $1 \mu \mathrm{L}$ of the sample was injected into the chromatograph at a split ratio of $1: 10$. The split/splitless injector was kept at $290^{\circ} \mathrm{C}$. The chromatographic column, initially at $80^{\circ} \mathrm{C}$, isothermal for $5 \mathrm{~min}$, was heated at a rate of $4{ }^{\circ} \mathrm{C}$ min- 1 to $260^{\circ} \mathrm{C}$ for $10 \mathrm{~min}$. After separating the compounds, the temperature was raised to $300{ }^{\circ} \mathrm{C}$ and maintained for 2 min (after running). The interface temperature was maintained at $280{ }^{\circ} \mathrm{C}$ and the ionization performed by impact of $70 \mathrm{eV}$. The $\mathrm{m} / \mathrm{z}$ sweep range was from 30 to $600 \mathrm{Da}$.

\subsection{Origin of Insects}

Native larvae of Culex quinquefasciatus were provided by the Montes Claros Zoonoses Control Center (Centro de Controle de Zoonoses-CCZ) and identified in accordance with the Cx. quinquefasciatus surveillance guide (Ministério da Saúde, 2011). The eggs of Aedes aegypti came from the F4 and F5 generations of the already established closed colony, provided by the insectarium of the Insect Behavior Laboratory of the Federal Institute of Northern Minas-Campus Salinas.

\subsection{Bioassays and Data Analysis}

The bioassays were carried out according to the methodology described by the WHO (1981). Final third instar or early fourth instar larvae were transferred to disposable plastic containers containing $30 \mathrm{~mL}$ of $\mathrm{AE}$ or negative control containing mineral water. Tests were performed in triplicate; 20 larvae of Ae. aegypti and $15 C x$. quinquefasciatus larvae were added to each container, and the final concentrations evaluated were $10.5 ; 7.875$; 
5.25 and $2.625 \mathrm{mg} / \mathrm{ml}$ and $21.0 ; 15.25 ; 10.5$ and $5.25 \mathrm{mg} / \mathrm{mL}$, respectively. After a period of 24 and 48 hours, the tests were evaluated, which included counting the dead larvae and observing the occurrence of morphological deformations by optical microscopy.

The experiments were carried out in a completely randomized split-plot design (treatments defined as concentrations and periods as subplots). The data were subjected to analysis of variance and the means were compared using the Scott-Knott test $(\mathrm{p}>0.05)$, using the SAEG 9.1 statistical package (2007). The concentration capable of promoting $90 \%$ larval mortality was determined by probit regression analysis $(p>0.05)$ in the same statistical program.

\section{Results}

\subsection{Effect of Tested Aqueous Extract on Culicidae Larvae}

The bioassays performed showed a significant interaction between the periods and concentrations tested $(\mathrm{p}<0.001)$ against Ae. aegypti and Cx. quinquefasciatus, obtaining greater efficacy after 48 hours of treatment. During this period, the AE of M. armata leaves showed $100 \%$ efficacy in the mortality of Ae. aegypti larvae at $\geq 7.87 \mathrm{mg} / \mathrm{mL}$ and efficacy of $88.7 \%$ against $C x$. quinquefasciatus larvae at $21 \mathrm{mg} / \mathrm{mL}$ (Table 1).

Table 1. Mortality of Aedes aegypti and Culex quinquefasciatus in larvae treated with aqueous extract of Mauritiella armata leaves after two periods

\begin{tabular}{lll}
\hline Treatments $(\mathbf{m g} / \mathbf{m L} \mathbf{)}$ & $\mathbf{2 4 h}$ & $\mathbf{4 8 h}$ \\
\hline Ae. aegypti & & \\
10.5 & $93.33 \mathrm{Aa}$ & $100.00 \mathrm{Aa}$ \\
7.88 & $60.00 \mathrm{Bb}$ & $100.00 \mathrm{Aa}$ \\
5.25 & $20.00 \mathrm{Bc}$ & $85.00 \mathrm{Ab}$ \\
2.625 & $6.67 \mathrm{Bd}$ & $21.67 \mathrm{Ac}$ \\
Mineral water & $0.00 \mathrm{Ae}$ & $0.00 \mathrm{Ae}$ \\
Cx. quinquefasciatus & & \\
21.00 & $48.67 \mathrm{Ba}$ & $89.00 \mathrm{Aa}$ \\
15.25 & $37.67 \mathrm{Bb}$ & $75.67 \mathrm{Ab}$ \\
10.50 & $26.67 \mathrm{Bc}$ & $55.67 \mathrm{Ac}$ \\
5.25 & $11.00 \mathrm{Bd}$ & $48.67 \mathrm{Ad}$ \\
Mineral water & $0.00 \mathrm{Ae}$ & $0.00 \mathrm{Ae}$ \\
\hline
\end{tabular}

Note. Distinct lowercase letters in columns indicate differences between treatments, and distinct uppercase letters in rows indicate differences between periods at $(\mathrm{p}<0.05)$.

After $24 \mathrm{~h}$ of incubation, larvae subjected to AE of M. armata leaves showed deterioration and induction of intestinal content elimination in both vectors (Figure 1).
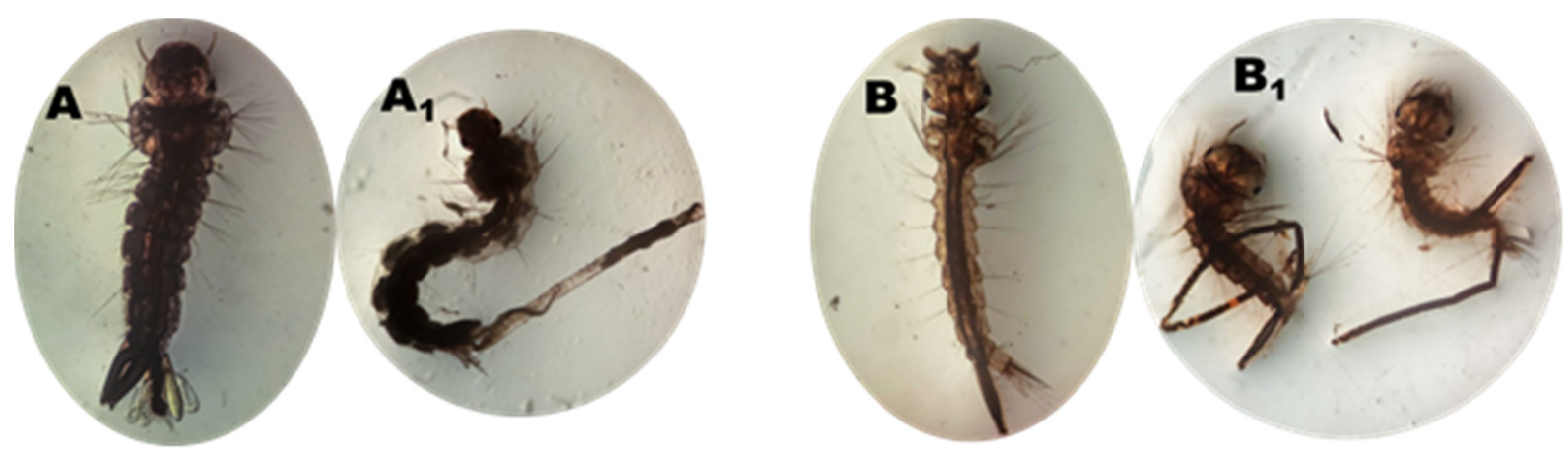

Figure 1. Aedes aegypti larva exposed to distilled water (A); Ae. aegypti larvae exposed for 48 hours to the aqueous extract of Mauritiella Armata (A1); Larvae of Culex. quinquefasciatus from the control group (B) and exposed to the extract (B1). Expansion by $400 \times$ (objective lens: $40 \times$, down: $10 \times$ ) 
For the larvae of Ae aegypti it was not possible to estimate the $\mathrm{CL}_{90}$, as it showed $100 \%$ mortality at low concentrations; however, the $\mathrm{CL}_{90}$ for Cx. quinquefasciatus larvae was estimated to be $30.57 \mathrm{mg} / \mathrm{mL}$ (25.57 - 39.10 $\mathrm{mg} / \mathrm{mL}$ ) (Figure 2).

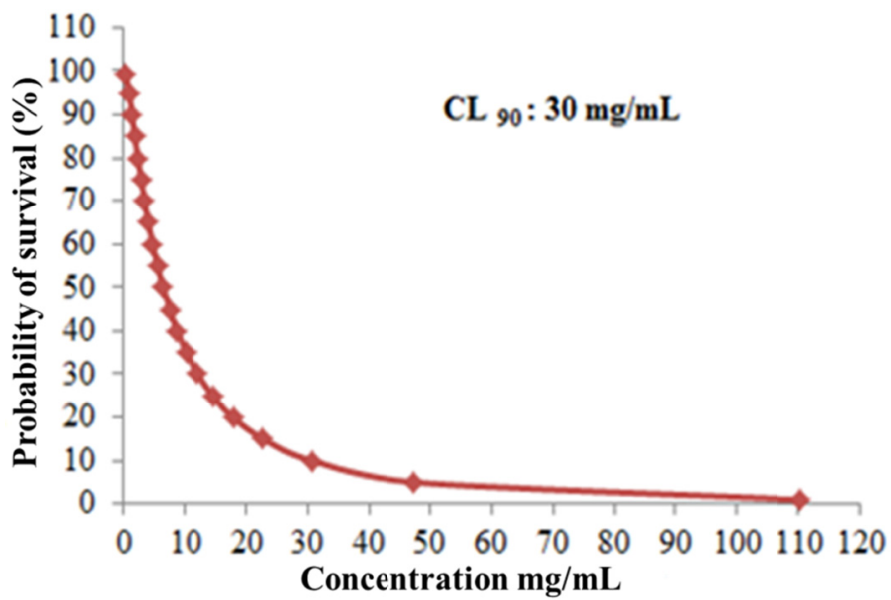

Figure 2. Probability of survival of Culex. quinquefasciatus larvae after $48 \mathrm{~h}$ of treatment with aqueous extract of Mauritiella armata leaves

\subsection{Phytochemical Analysis}

In the phytochemical analysis, carbohydrates, tannins, and acids were identified in the $\mathrm{AE}$ of M. armata leaves. The largest classes according to the size of their areas were carbohydrate- $\beta$-D-glucopyranose $(18.46 \%)$ and carbohydrate-thalose $(10.33 \%)$; in addition, the presence of catechin $(0.05 \%)$ was observed.

Table 2. Compounds identified by gas chromatography in Mauritiella armata leaf extracts and their area (\%) in the chromatographic profile.

\begin{tabular}{llll}
\hline \multicolumn{3}{c}{ Aqueous extract } \\
\hline $\mathbf{N}$ & RT & Compounds (Area\%) & $\mathbf{n}$ \\
\hline 1 & 7.312 & 2-hydroxypropanoic acid & 0.18 \\
3 & 8.805 & L-alanine & 0.06 \\
4 & 9.766 & Glyconic acid & 0.16 \\
11 & 17.909 & Phosphate & 1.35 \\
12 & 15.035 & Glycerol & 0.82 \\
13 & 16.381 & Butanedioic acid & 0.06 \\
18 & 22.116 & 2-hydroxybutanedioic acid & 0.39 \\
28 & 31.343 & Carbohydrate- $\beta$-D-Glycopyranosis & 18.46 \\
34 & 33.129 & Carbohydrate- $\beta$-D-Glycopyranosis & 10.68 \\
35 & 33.288 & Carbohydrate-galactopyranose & 5.95 \\
43 & 35.530 & Carbohydrate-talose & 10.33 \\
47 & 37.420 & Carbohydrate- $\beta$-D-Galactofuranosis & 1.62 \\
48 & 37.900 & Carbohydrate-Inositol & 5.34 \\
62 & 54.551 & Catechin & 0.05 \\
\hline
\end{tabular}

Note. RT: Retention time (min.); N.I.: 1.

\section{Discussion}

Aqueous extracts from leaves appear as an alternative for vector control. In the literature, extracts of Annona glabra, Bougainvillea spectabilis, and Saraca asoca with larvicidal activity in larvae of Ae. aegypti and Aedes, and Ae. Albopictus, with $\mathrm{LC}_{50}$ of $5.29 \mathrm{mg} / \mathrm{L}$ and $3.02 \mathrm{mg} / \mathrm{L}$ respectively (Amarasinghe et al., 2020; Sharma et al., 2019) 
stand out. Likewise, for Cx. quinquefasciatus AE from leaves of Cassia didymabotrya and Cayratia trifolia showed 100\% mortality efficacy (Nagappan, 2012; Chakraborty et al., 2013).

The results obtained demonstrate that the AE of $M$. armata leaves presented larvicidal potential at the evaluated concentrations. In $48 \mathrm{~h}$, there was a higher mortality of larvae in both insects. This fact corroborates the results of Hari and Mathew (2018), who in the same period, observed higher larval mortality of Ae. aegypti and Cx. quinquefasciatus through a combination of plant extracts. According to Santos et al. (2015), the longer the exposure time of larvae to the $\mathrm{AE}$, the higher the mortality percentages, due to the absorption of toxic substances.

The control larvae of both insects showed high mobility and quick reaction to any touch. In contrast, larvae submitted to AE showed loss of mobility and morphological changes after $24 \mathrm{~h}$ of treatment. According to Barreto et al. (2007), the first sign of the extract's larvicidal action is the reduction of larval mobility.

Additionally, the AE from the leaves of $M$. armata caused deterioration and induction of elimination of the intestinal contents of the larvae of both vectors (Figure 2). Procopio et al. (2015), observed a similar effect on $A$. aegypti larvae exposed to the leaf extract of Schinus terebinthifolius (Anacardiaceae). This behavior has been reported as a defense mechanism of mosquito larvae in order to expel substances that are toxic to them (Gusmão et al., 2002). Although the larvae present this defense mechanism, our results showed that this was not enough to avoid the harmful effects of the extract, since the larvae survival rate decreased after the larvicide test.

Assessing the chemical composition of M. armata, Royo et al. (2019) detected significant flavonoid content in its leaves, petiole and root. Flavonoids are a diverse and abundant group among secondary metabolites in different plants (Filho, Antonio Carlos Pereira; Castro, 2019). In the study by Tayler et al. (2019), EA from leaves of Cocos nucifera (Arecaceae) showed antiparasitic activity against the malaria protozoan, due to the synergistic action of flavonoids with other compounds.

Diterpene extracted from Copaifera reticulata, and a fraction rich in catechetical tannins, extracted from Magonia pubescens caused the death of Ae. aegypti through cell destruction in the midgut (Volotto et al., 2011). In the work by Elumalai et al. (2016), the catechin isolated from Leucas aspera showed 100\% mortality in Ae aegypti, Anopheles stephensi and Cx. quinquefasciatus at a concentration of $20 \mathrm{ppm}$. The catechin, which has insecticidal properties, was identified in the phytochemical analysis of the xiriri leaf.

The aqueous extract of the leaves of Mauritiella armata represents a promising alternative for the control of Aedes aegypti and Culex quinquefasciatus, due to its high larvicidal effect. In addition, this study presents a simple, clear, and low-cost methodology that contributes to the valuation of ecosystem services and the promotion of unique health.

\section{Acknowledgements}

To the team from the Montes Claros Zoonoses Control Center, from the SUDOTROP Laboratory at the State University of Montes Claros, and from the Parasitology Laboratory at the Federal University of Minas Gerais.

\section{References}

Amarasinghe, L. D., Wickramarachchi, P. A. S. R., Aberathna, A. A. A. U., Sithara, W. S., \& De Silva, C. R. (2020). Comparative study on larvicidal activity of green synthesized silver nanoparticles and Annona glabra (Annonaceae) aqueous extract to control Aedes aegypti and Aedes albopictus (Diptera: Culicidae). Heliyon, 6(6), e04322. https://doi.org/10.1016/j.heliyon.2020.e04322

Andrade Royo, V. de, Rocha, J. A., Santos, K. T., Freitas, J. F. L., Almeida, C. A., Ribeiro, B., Menezes, E. V., Oliveira, D. A. de, Brandao, M. M., \& Junior, A. F. de M. (2019). Comparative Studies Between Mauritia flexuosa and Mauritiella armata. Pharmacognosy Journal, 11(1), 32-36. https://doi.org/10.5530/ pj.2019.1.6

Andrew Henderson, G. G. e R. B. (1995). Field Guide to the Palms of the Americas. Princeton, USA.

Atyame, C. M., Alout, H., Mousson, L., Vazeille, M., Diallo, M., Weill, M., \& Failloux, A.-B. (2019). Insecticide resistance genes affect Culex quinquefasciatus vector competence for West Nile virus. Proceedings of the Royal Society B: Biological Sciences, 286(1894), 20182273. https://doi.org/10.1098/rspb.2018.2273

Barreto, C. F., Cavasin, G. M., Garcia da Silva, H. H., \& Da Silva, I. G. (2007). Study of Morpho-histological Changes in Aedes aegypti Larves (Diptera, Culicidae) Submitted to the Sapindus saponaria Lin (Sapindaceae) Gross Ethanolics. Revista de Patologia Tropical, 35(1), 37-57. https://doi.org/10.5216/rpt.v35i1.1891

Brasil. (2011). Guia de vigilância do Culex quinquefasciatus (3rd ed., B). Ministério da Saúde, Secretaria de 
Vigilância em Saúde, Departamento de Vigilância Epidemiológica, Coordenação Francisco Anilton Alves Araújo, Marcelo Santalucia. Retrieved from https://bvsms.saude.gov.br/bvs/publicacoes/guia_vigilancia culex_quinquefasciatus.pdf

Chakraborty, S., Singha, S., Bhattacharya, K., \& Chandra, G. (2013). Control of human filarial vector, Culex quinquefasciatus Say 1823 (Diptera: Culicidae) through bioactive fraction of Cayratia trifolia leaf. Asian Pacific Journal of Tropical Biomedicine, 3(12), 980-984. https://doi.org/10.1016/S2221-1691(13)60189-6

Donalisio, M. R., Freitas, A. R. R., \& Zuben, A. P. B. Von. (2017). Arboviruses emerging in Brazil: challenges for clinic and implications for public health. Revista de Saúde Pública, 51. https://doi.org/10.1590/ s1518-8787.2017051006889

Elumalai, D., Hemavathi, M., Hemalatha, P., Deepaa, C. V., \& Kaleena, P. K. (2016). Larvicidal activity of catechin isolated from Leucas aspera against Aedes aegypti, Anopheles stephensi, and Culex quinquefasciatus (Diptera: Culicidae). Parasitology Research, 115(3), 1203-1212. https://doi.org/10.1007/ s00436-015-4856-6

Filho, A. C. P., \& Castro, C. F. de S. (2019). Classes Fitoquímicas De Metabólitos Secundários Em Extratos Etanólicos Foliares De Espécies Do Cerrado Phytochemical Classes of Secondary Metabolites in Foliary Ethanolic Extracts From Species of Brazilian. Revista Saúde \& Ciência Online, 8, 45-61.

Gray, L., Florez, S. D., Barreiro, A. M., Vadillo-Sánchez, J., González-Olvera, G., Lenhart, A., Manrique-Saide, P., \& Vazquez-Prokopec, G. M. (2018). Experimental evaluation of the impact of household aerosolized insecticides on pyrethroid resistant Aedes aegypti. Scientific Reports, 8(1), 12535. https://doi.org/10.1038/ s41598-018-30968-8

Gusmão, D. S., Páscoa, V., Mathias, L., Vieira, I. J. C., Braz-Filho, R., \& Lemos, F. J. A. (2002). Derris (Lonchocarpus) urucu (Leguminosae) Extract Modifies the Peritrophic Matrix Structure of Aedes aegypti (Diptera: Culicidae). Memórias do Instituto Oswaldo Cruz, 97(3), 371-375. https://doi.org/10.1590/S007402762002000300017

Hari, I., \& Mathew, N. (2018). Larvicidal activity of selected plant extracts and their combination against the mosquito vectors Culex quinquefasciatus and Aedes aegypti. Environmental Science and Pollution Research, 25(9), 9176-9185. https://doi.org/10.1007/s11356-018-1515-3

Hwang, K. S., Kim, Y. K., Park, K. W., \& Kim, Y. T. (2017). Piperolein B and piperchabamide D isolated from black pepper (Piper nigrum L.) as larvicidal compounds against the diamondback moth (Plutella xylostella). Pest Management Science, 73(8), 1564-1567. https://doi.org/10.1002/ps.4580

Koc, S., Evren, O. H., \& Cetin, H. (2016). Evaluation of Some Plant Fruit Extracts for the Control of West Nile Virus Vector Culex pipiens (Diptera: Culicidae). Journal of Arthropod-Borne Diseases, 10(4), $595-601$. http://www.ncbi.nlm.nih.gov/pubmed/28032112

Linnaeus, C. (1762). Zweyter Theil, Enthalt Beschreibungen Verschiedenerwichtiger Naturalien.

Lopes, R. P., Lima, J. B. P., \& Martins, A. J. (2019). Insecticide resistance in Culex quinquefasciatus Say, 1823 in Brazil: a review. Parasites \& Vectors, 12(1), 591. https://doi.org/10.1186/s13071-019-3850-8

Martins, R. C. (2012). The Arecaceae Family (Palmae) in the State of Goiás: Floristic and Ethnobotanical. Retrieved from http://www.teses.usp.br/teses/disponiveis/12/12139/tde-\%0A24012002-114443

Morais-Costa, F., Soares, A. C. M., Bastos, G. A., Nunes, Y. R. F., Geraseev, L. C., Braga, F. C., dos Santos Lima, W., \& Duarte, E. R. (2015). Plants of the Cerrado naturally selected by grazing sheep may have potential for inhibiting development of Haemonchus contortus larva. Tropical Animal Health and Production, 47(7), 1321-1328. https://doi.org/10.1007/s11250-015-0866-8

Nagappan, R. (2012). Evaluation of aqueous and ethanol extract of bioactive medicinal plant, Cassia didymobotrya (Fresenius) Irwin \&amp; Barneby against immature stages of filarial vector, Culex quinquefasciatus Say (Diptera: Culicidae). Asian Pacific Journal of Tropical Biomedicine, 2(9), 707-711. https://doi.org/10.1016/S2221-1691(12)60214-7

Nery, P. S., Nogueira, F. A., Martins, E. R., \& Duarte, E. R. (2010). Effects of Anacardium humile leaf extracts on the development of gastrointestinal nematode larvae of sheep. Veterinary Parasitology, 171(3-4), 361-364. https://doi.org/10.1016/j.vetpar.2010.03.043

Patricia Cunniff. (1995). Cunniff. Washington, DC: Association of Official Analytical Chemists. Retrieved from https:/www.worldcat.org/title/official-methods-of-analysis-of-aoac-international/oclc/421897987 
Procópio, T. F., Fernandes, K. M., Pontual, E. V., Ximenes, R. M., de Oliveira, A. R. C., Souza, C. de S., ... Napoleão, T. H. (2015). Schinus terebinthifolius Leaf Extract Causes Midgut Damage, Interfering with Survival and Development of Aedes aegypti Larvae. PLoS ONE, 10(5), e0126612. https://doi.org/ 10.1371/journal.pone.0126612

Santos, I. P. C. dos, Cruz, R. C. D. da, Carvalho, K. da S., Silva, S. L. da C., \& Gualberto, S. A. (2015). Bioatividade de extratos aquosos da parte aérea de poincianella bracteosa sobre larvas de Aedes aegypti. Enciclopédia Biosfera, 11(21), 2908-2915. Retrieved from http://www.conhecer.org.br/enciclop/2015b/ multidisciplinar/Bioatividade de extratos.pdf

Say, T. (1823). Descriptions of Dipterous Insects of the United States.

Sharma, A., Tilak, R., \& Sisodia, N. (2019). Evaluation of bioactivity of aqueous extracts of Bougainvillea spectabilis, Saraca asoca, and Chenopodium album against immature forms of Aedes aegypti. Medical Journal Armed Forces India, 75(3), 308-311. https://doi.org/10.1016/j.mjafi.2018.07.013

Tayler, N. M., Boya, C. A., Herrera, L., Moy, J., Ng, M., Pineda, L., ... Spadafora, C. (2019). Analysis of the antiparasitic and anticancer activity of the coconut palm (Cocos nucifera L. ARECACEAE) from the natural reserve of Punta Patiño, Darién. PLOS ONE, 14(4), e0214193. https://doi.org/10.1371/ journal.pone.0214193

Valotto, C. F. B., Silva, H. H. G. da, Cavasin, G., Geris, R., Rodrigues Filho, E., \& Silva, I. G. da. (2011). Alterações ultraestruturais em larvas de Aedes aegypti submetidas ao diterpeno labdano, isolado de Copaifera reticulata (Leguminosae), e à uma fração rica em taninos de Magonia pubescens (Sapindaceae). Revista da Sociedade Brasileira de Medicina Tropical, 44(2), 194-200. https://doi.org/10.1590/S003786822011005000010

WHO. (1981). Instructions for Determining the Susceptibility or Resistance of Mosquito Larvae to Insecticides. Retrieved from https://apps.who.int/iris/bitstream/handle/10665/69615/WHO?sequence=1

WHO. (2018). Ministros da Saúde das Américas fazem acordo para fortalecer ações de prevenção às doenças transmitidas por vetores. OMS. Retrieved from https://www.paho.org/pt/noticias/25-9-2018-ministros-dasaude-das-americas-fazem-acordo-para-fortalecer-acoes-prevencao

\section{Copyrights}

Copyright for this article is retained by the author(s), with first publication rights granted to the journal.

This is an open-access article distributed under the terms and conditions of the Creative Commons Attribution license (http://creativecommons.org/licenses/by/4.0/). 